\title{
A Multisector Framework for Assessing Community-Based Forest Management: Lessons from Madagascar
}

\author{
${\text { Daniela B. } \text { Raik }^{1} \text { and Daniel J. Decker }}^{1}$
}

\begin{abstract}
Community-based forest management has proliferated throughout Africa as national governments have decentralized the administration of public forestry. Community-based forestry has taken multiple forms, depending on the assortment of land-tenure systems, forest-use norms, wood demand, and social organization, among others factors. Nature, Wealth, and Power is an analytical framework that has been developed from experiences in natural resource management in Africa. In this paper, we amend the framework to People, Nature, Wealth, and Power (PNWP), and propose it as an analytical lens for community-based forest management initiatives. We use the PNWP framework to assess the responsiveness of contractual forest management in the Menabe region of Madagascar to the interests of local communities, the state forest agency, and conservation nongovernmental organizations. Findings indicate that members of each of the three groups hold some differing interests, which may result in conflict over time. Specifically, interests converge around the Nature and Wealth categories and diverge around the People and Power categories. Also, the contract mechanism for community-based forest management currently being implemented in Menabe does not account for the People and Wealth interests held by any of the three groups. More research is needed, but our inquiry indicates the PNWP framework holds promise for assessing community-based forest management initiatives.
\end{abstract}

Key Words: community-based forest management; decentralization; forestry; Madagascar

\section{INTRODUCTION}

Throughout Africa, national governments are decentralizing authority in the fields of health service provision, education systems, public works, and forestry (Agrawal and Ribot 1999, Ribot 2002). Decentralization has taken many forms, including democratic decentralization, which is an act by which the central government relinquishes power to local entities that are accountable to local people, e.g., the local community (Bergh 2004). This kind of action is part of a broader trend toward populist approaches to development interventions. These approaches are evident in the plethora of participatory appraisal techniques developed over the last $20 \mathrm{yr}$, and the tendency to direct interventions at the local level (e.g., Kiss 1990, Hildyard et al. 2001). The rationale behind decentralization efforts and participatory approaches rests in part on the idea of subsidiarity, i.e., decisions should be made at the lowest administrative level possible (Uphoff 1986). Outcomes attributed to decentralization include bureaucratic efficiency, procedural equity among administrative levels of government, increased service provision, citizen participation, and maintenance of political stability (Ribot 2002).

Decentralization of government authority has extended to the forestry sector in many African nations (e.g., Oyono 2004, Wiggins et al. 2004). The movement toward community-based forest management regimes is a manifestation of this trend (e.g., Vabi et al. 2000, Brown and Schreckenberg 2001, Edmonds 2002). However, despite the positive rhetoric around community-based forest management, efforts to decentralize forest governance to local entities have had mixed results (Blaikie 2006). Efforts to increase citizen participation, devolve authority, and create more efficient and equitable structures for managing resources have failed when decision-making powers have remained centralized or have been captured by elites unaccountable to local people (e.g., Gauld 2000, Platteau 2004, 
Blaikie 2006). Efforts to increase conservation areas have often failed because communities continue to use timber resources for daily needs or strike deals with commercial timber harvesters. Finally, community-based forest management for the purpose of stimulating economic development has frequently failed when transparency and accountability in local communities and governments are lacking (Larson and Ribot 2004).

Studies have identified the conditions under which decentralized, community-based forest management is most likely to succeed (Ostrom 1990, Adams and Hulme 2001, Pagdee et al. 2006). These studies have focused retrospectively on understanding what worked and what did not work. In this paper, we argue that efforts to decentralize authority in the forest sector are not meeting their potential, in part because of the narrow, sector-specific manner in which decentralized forest-related structures and activities are conceived and put into place. The forests in question often have high economic and/ or biodiversity value. However, the people who live in these forests, depend on them for their livelihoods, and are the entity to which management authority is transferred are often poor and marginalized populations (Brechin et al. 2003, Borrini-Feyerabend et al. 2004). These people do not live sector-specific lives in terms of forests alone; they may be farmers or grazers and live their lives as whole people (see Selznick 1992). They concern themselves with issues in many sectors, including health, education, and business, and with issues that cross sectors, such as social cohesion, culture, and family, simultaneously and in an integrated and interactive fashion. To conceptualize their relationship with forests too narrowly, as their primary economic base or a dominant focus of their culture, can lead to inadequate policy. Thus, we propose that efforts to decentralize forest management may be more responsive to local realities if the process and the design of institutional structures, interventions, and activities reflect the multisector nature of people's lives. Given the financial and social hardships that many forest communities face, decentralization, among other governance arrangements that can respond to realities beyond the forest sector, may be the only way to ensure that the remaining tropical forests provide the resources people need while they are managed sustainably for future generations.

\section{PEOPLE, NATURE, WEALTH, AND POWER}

After decades of designing, implementing, and evaluating natural resource management initiatives in Africa, a consortium of institutions working in development reflected on their experiences and developed a framework that describes those efforts that seemed to have had positive results for local people. This framework, called "Nature, Wealth, and Power" (NWP), was offered as a lens through which analysis can be conducted, discussions can be structured, and current and future natural resources management initiatives can be designed (USAID et al. 2002). The framework recognizes the complexities of natural resources management and describes linkages among various sectors related to natural resources. Specifically, the framework draws on cases in which natural resources management led to increased resource productivity, increased conservation, and increased access to resource use for local people. The framework is made up of three components:

1. Nature: Natural resources of all types, e.g., land, water, forests, wildlife, that are "dynamic, socially embedded, economic and political" (USAID et al. 2002:4). It describes the gamut of natural resources that have economic, cultural, existence, aesthetic, biodiversity, or other values.

2. Wealth: Natural capital, which is the basis of rural production and economic development systems across Africa. This component represents the economic concerns of natural resources management.

3. Power: Governance, which refers to the interactions among structures, processes, rules, and traditions that determine how authority is exercised, how responsibilities are distributed, how decisions are made, and how various actors are involved (Hempel 1996).

The NWP framework emphasizes that natural resources management extends beyond the biological and physical manipulation of resources. Given that natural resources are embedded in the social and political fabric of society and government, issues of economic value, production, markets, laws, norms, access, and rights come into play when decisions are made about how to manage 
resources (e.g., Peluso 1993, Brechin et al. 2003, Menzies 2004). Thus, the NWP framework is an articulation of how programs that integrate across environment, economy, and governance result in positive impacts (USAID et al. 2002).

Although this framework articulates links among sectors and recognizes the multi- and intersector character of natural resources management, it does not sufficiently emphasize several additional linkages that can be clustered under the broad category "People." The links between natural resources and health, education, and communication are missing from the NWP framework (e.g., Chivian 2001, Chivian and Bernstein 2004). These linkages are important insofar as conservation activities are tied to development interventions in developing countries. Although one could argue that health and education are forms of wealth, we believe that a distinction between these categories allows for more nuanced analysis. For instance, undertaking forest management activities requires that local people, $i$. e., forest users, be in good health. Without sufficient nutrition and potable water, forest management activities cannot be completed. Biodiversity can contribute to human health by keeping diseasecausing organisms in check, providing medicinal plants, contributing to clean water and air, and mitigating the effects of climate change (Chivian and Bernstein 2004). Pressure on the forest from local populations is related to population growth (McKee 2004), among other factors such as migration and livelihood strategies. As the number of households per settlement increases, the need to clear additional land for dwellings or agriculture also increases. Family planning activities therefore have a direct link with forest management. These links are so apparent that the President of Madagascar was moved to write a letter to WorldView magazine titled "Madagascar Naturellement: Birth Control is My Environmental Priority" (Ravalomanana 2006). The links between natural resources and education and communication are equally important. Environmental education and communication convey information to people that may influence attitudes and behaviors regarding natural resources practices. In addition, basic education, especially for girls, reduces family size, thereby alleviating pressures on forest resources.

In response to the shortcomings we identified in NWP, we have amended that framework to reflect a more populist perspective (Fig. 1). This adaptation, which we refer to as "People, Nature,
Wealth, and Power," illustrates the links that exist among environmental management, economic growth, governance, and health and education activities for the goal of forest management in rural areas populated by people living primarily in a subsistence economy. The linkages are depicted in a hierarchy consistent with current thinking on national priorities in Madagascar and elsewhere. Wealth is at the top, reflecting the overall outcome anticipated from sustainable economic development or poverty reduction, as stated in many national policies of African nations (e.g., Government of Burkina Faso 2004, Government of Madagascar 2004) and donor strategy statements (e.g., Klugman 2002, USAID 2002). People and Nature are at the bottom, because they represent the foundation of rural society in many developing countries. Power represents governance, which is cross-cutting and an integral part of the other three elements. Thus Power is at the center. The two-way arrows among elements illustrate the interdependent and interactive nature of policies and interventions in each sector. This hierarchical conceptualization of the multisector linkages was identified as valid for the case of Madagascar during a brainstorming workshop held by USAID/Madagascar in July 2005.

\section{CONTRACTUAL FOREST MANAGEMENT IN MADAGASCAR: A CASE FOR PEOPLE, NATURE, WEALTH, AND POWER}

Madagascar is regarded as one of the most biologically rich areas on Earth, with nearly $80 \%$ of its flora and fauna endemic to the island (Lourenco 1996, Goodman and Benstead 2003). Madagascar is also home to a unique dry forest ecosystem located in the Menabe region (Figs. 2 and 3). Primary forest cover in the western dry forests of Madagascar declined from $12.5 \%$ in 1950 to $2.8 \%$ in 1990 (Smith et al. 1997). Western Madagascar is also among the most economically depressed regions of the country because of its short growing season and poor soils (Sorg et al. 2003). Efforts to curb deforestation and conserve threatened and endangered species have been undertaken by the Malagasy government and by international conservation and development organizations. These efforts have coincided with a government-wide decentralization movement that includes transferring management rights and responsibilities from the state forest agency to local communities. 
Fig. 1. People, Nature, Wealth, and Power provides a conceptual framework to guide the assessment of the responsiveness of community-based forest management efforts to local needs.

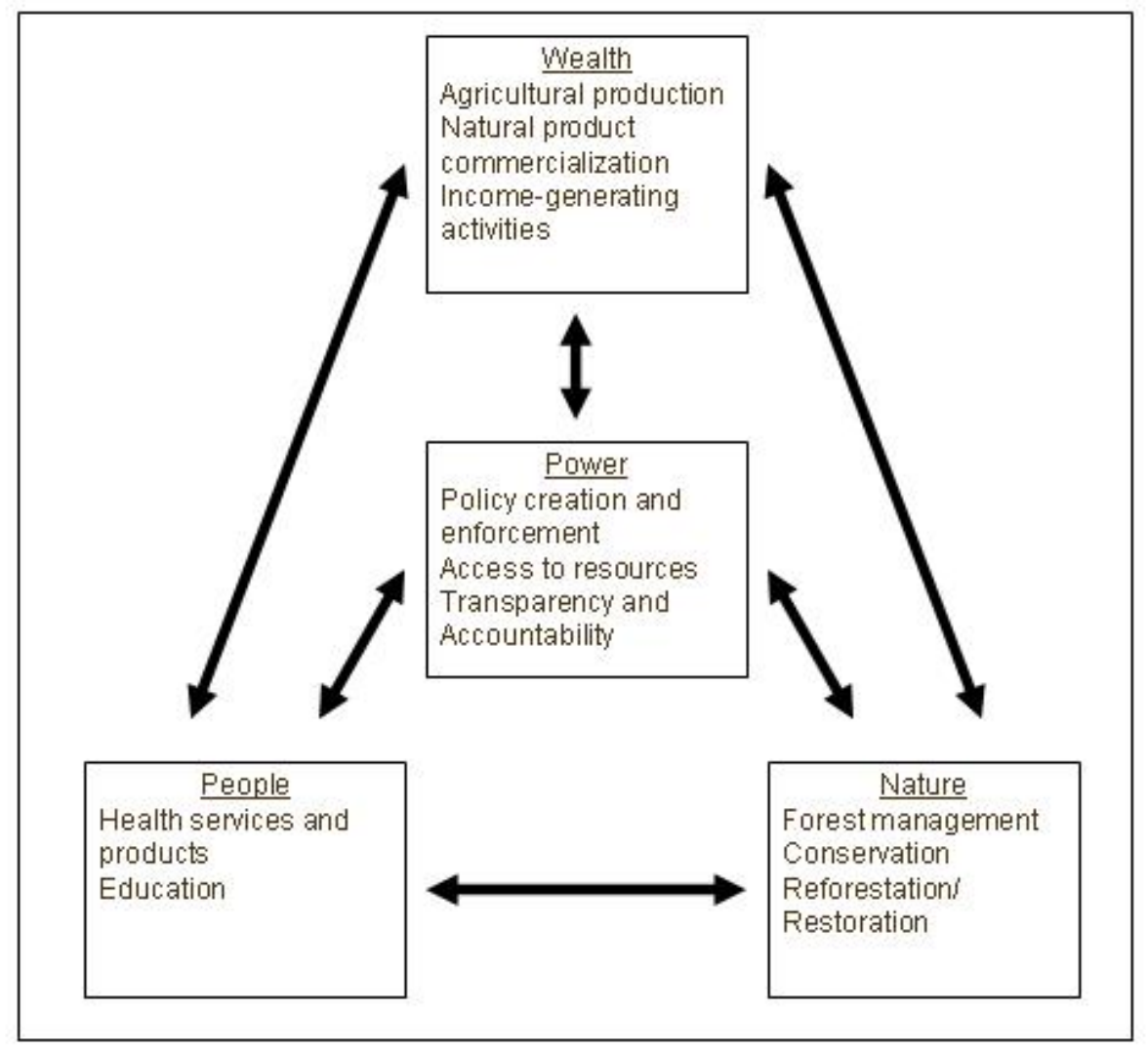

National forestry policy \#2001-122 establishes the legal framework for contractual forest management, or Gestion Contractualisée des Forêts (GCF; Eaux et Forêts 2002). Under the GCF arrangement, local communities enter into a contractual agreement with the Malagasy forest service, the DGEF (Direction Générale des Eaux et Foréts), regarding the use and management of local forested lands. In most cases, the contracting process is facilitated by a third party that is either a conservation or a development organization (Randrianasolo 2000, Montagne 2004).
GCF contracts are signed between the DGEF and a community-level forest association that is formed for this purpose (COBA). The DGEF's mission is to act as a steward of all Malagasy forest resources. Specific activities include zoning for conservation, production, and reforestation and overseeing the implementation of management plans for each of these zones. The COBA is made up of local forest users, primarily local residents who use forests for firewood, timber, medicinal plants, food, and cultural practices. To be granted a contract, a COBA must have official standing as an association and be sanctioned by the mayor's office. The intended 
Fig. 2. Map of Madagascar indicating location of Menabe region.

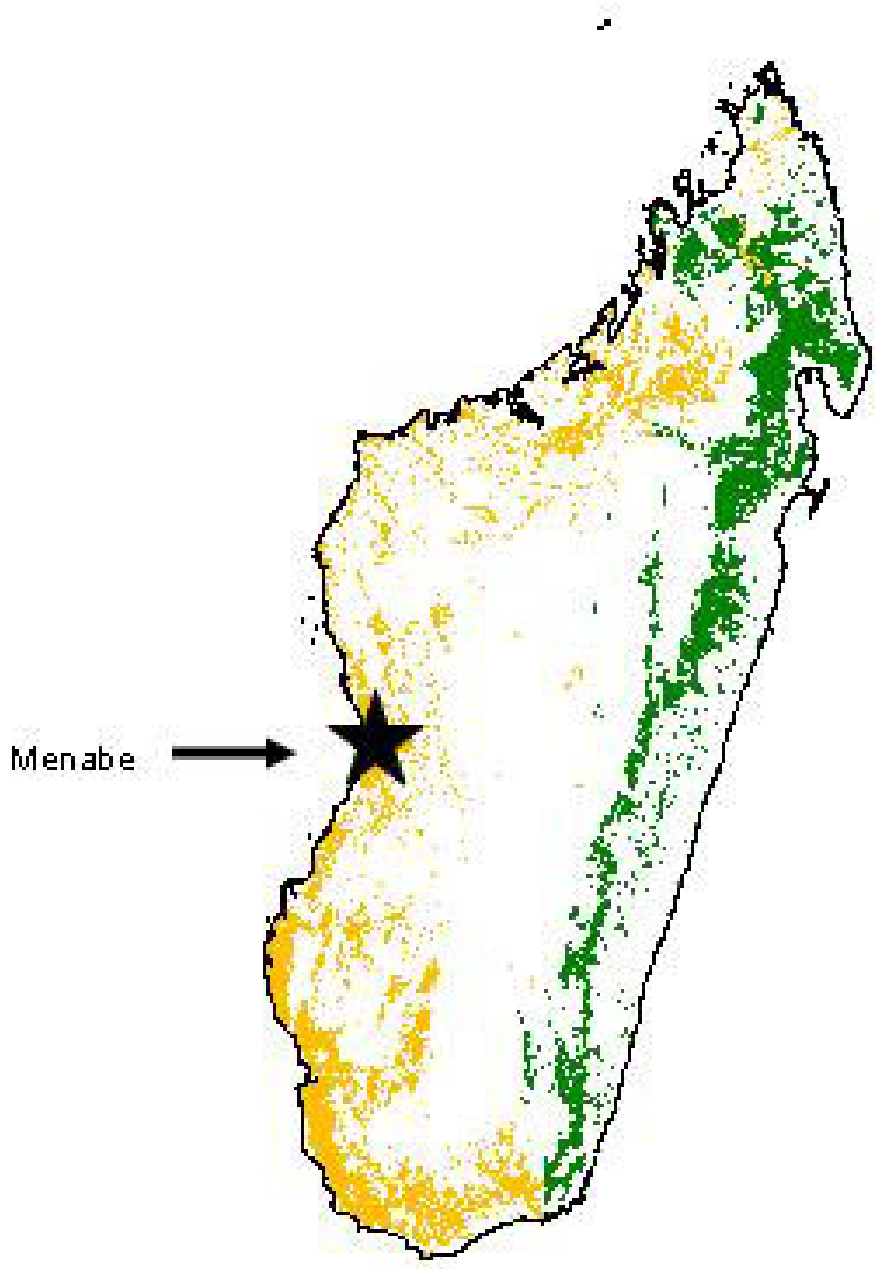

relationship between the DGEF and the COBA under the GCF arrangement is that both the forest agency and the community association will benefit. The forest agency serves as technical advisor to the community to ensure that sound forest management practices are implemented, and the COBA implements, monitors, and evaluates management.

Initial GCF contracts are granted for 3 yr. If all the parties involved agree that the GCF is being properly managed at the end of this initial period, the contract can be renewed for $10 \mathrm{yr}$. Areas of forest that are under GCF contract are zoned into three parts: a conservation zone with no extraction of any resources, a sustainable-use zone for daily-use resource extraction, and a commercial zone
(CIRAD et al. 2002). Currently, approximately 300 GCF contracts exist in Madagascar, eight of which are in Menabe (RESOLVE Conseil 2005).

The Menabe region of Madagascar was selected for this study because it was a pilot region for community-based forest management even before the official GCF legislation was finalized. With the support of international donors and NGOs, the forest agency began the process of transferring forest management to local communities in Menabe in the early 1990s. The additional years of experience of GCFs in Menabe, as opposed to other regions of Madagascar, offer insight into a process that has developed over time. 
Fig. 3. Baobob Alley in Central Menabe.

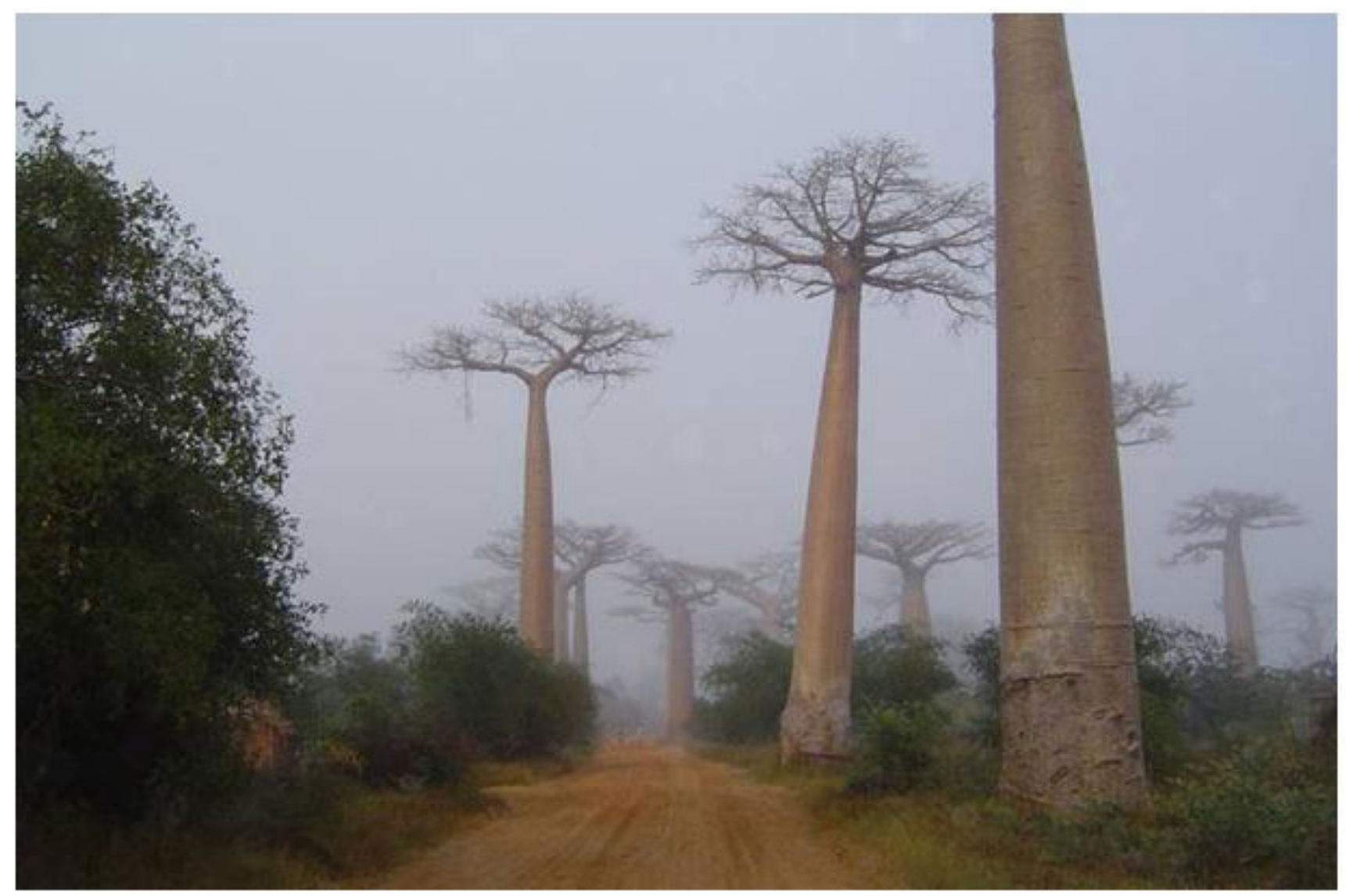

The benefits of GCF contracts in Madagascar and community-based forest management initiatives elsewhere will depend in part on the extent to which they respond to the interests of the various parties involved. People, Nature, Wealth, and Power (PNWP) offers a framework for analyzing the multisector interests held by various actors, thus facilitating assessment of the responsiveness of decentralized, community-based forest management. The objectives of the exploratory research conducted in this study were to: (1) identify interests related to forest management held by the state, the community, and the NGO representatives; (2) apply the PNWP framework as a lens for classifying these interests; and (3) conduct an initial assessment of the extent to which the GCF mechanism responds to various interests held by the multiple actors.

\section{METHODS}

We conducted a total of 55 semistructured, openended interviews (LeCompte and Preissle 1993, Seidman 1998) of community members in all eight villages in the Menabe region with Gestion Contractualisée des Forêts (GCF) contracts ( $n=$ $31)$, state forest agents at the local and national levels $(n=11)$, and participating NGO staff from two NGOs at the local and national levels in Menabe and Antananarivo, Madagascar $(n=13)$. Semistructured interviews are appropriate in predetermined, formal field settings when the purpose is phenomenological (Denzin and Lincoln 2000). In the case of Menabe, the NGOs in question have a biodiversity conservation mandate. Individuals were sampled using a snowball 
sampling methodology (LeCompte and Preissle 1993, Miles and Huberman 1994) to ensure that subjects with knowledge of and experience in the GCF process were included in the study. The sample reached saturation when redundancy occurred in the individuals identified.

Interviews lasted between 45 and 90 min and were conducted in person in the local language. No translator was used because we are proficient in the local language. In addition, we conducted participant-observation (LeCompte and Preissle 1993, Miles and Huberman 1994) by attending workshops, participating in GCF-related discussions and field trips, and accompanying forest users to collect forest products. Data collection occurred over the three-month period from June to August 2004. Interview questions focused on experiences to date with GCF, expectations for GCF, interests related to $\mathrm{GCF}$, perceived problems regarding $\mathrm{GCF}$ implementation, and future expectations.

Permission to conduct research in Madagascar was granted by the Department of Water and Forests in the Ministry of Environment, Water, and Forests in Antananarivo, Madagascar. In addition, the methods used in this research were approved by the appropriate institutional human subjects' committees for the duration of the research project. Our protocol included communicating risks to participants and maintaining confidentiality.

Qualitative, inductive inquiry facilitated an initial understanding of the social dynamics that characterize community-based forest contracts. Given the exploratory nature of this study, we felt this approach was more appropriate for our purposes than a deductive, quantitative survey. Following the tenets of grounded theory (Glaser and Strauss 1967), which aims to cultivate theory about a phenomenon, an iterative approach guided our data analysis. Notes were taken during interviews, and those notes were then written up in narrative form. We refrained from tape-recording and transcribing interviews, because this practice is culturally inappropriate in the rural setting of Menabe. Interview notes were coded using the People, Nature, Wealth, and Power (PNWP) framework for each of the categories of actors, i.e., community, forest agency, NGO. The coded data were then grouped into the PNWP categories in tabular form (Miles and Huberman 1994).

In seeking to understand the practice of forest contracts, and the multisector interests that combine to shape the agendas advanced by various actors, we deliberately sampled forest users, forest agency personnel, and participating NGO staff. Care should be taken in assessing contextual similarities and differences when considering the implications of this study for other cases. In addition, our inductive approach does not allow for reproduction or prediction, but sheds light on a complex governance structure that involves various institutional actors. Future research addressing the broader implications of a multisector approach to decentralized forest management would be of value.

\section{FINDINGS}

Individual interviews revealed interests related to the People, Nature, Wealth, and Power (PNWP) categories held by community forest users, the state forest agency, and NGO staff (Table 1). Results were compiled for all eight communities studied. Results from participant observation affirm the interview results. The italicized cells in Table 1 indicate interests that are not being met under current Gestion Contractualisée des Forêts (GCF) management arrangements in Menabe. Despite many similarities among the three classes of actors, i.e., state, community, and $\mathrm{NGO}$, the interests of each of the three groups differ somewhat for several of the four analytical categories, as described below.

\section{Community forest users}

Forest users in the Menabe region reported that GCF contracts contributed to their ability to continue to access the forest for purposes of collecting construction materials, medicinal plants, food, and fuel. They linked this ability to use forest resources to the overall health and functionality of their communities. Forest users stressed the linkages between forest health and community health, and indicated great satisfaction from having stateapproved access to forests for medicinal plants. They also indicated that the GCF contracts contributed to their ability to ensure that forest resources would be accessible for use by future generations.

Forest users did not feel that the GCF contracts met their needs with respect to the Wealth and Power elements of forestry. Specifically, some people were of the opinion that the GCF arrangements did not ensure financial benefit to the community from 
Table 1. Interests held by various Gestion Contractualisée des Forêts (GCF) parties related to People, Nature, Wealth, and Power. Italics indicate interests that are not met by the current GCF contracts in Menabe. COBA is an acronym for community-level forest association.

\begin{tabular}{|c|c|c|c|}
\hline Analytical framework & COBA/Community & State forest agency & Conservation-oriented NGO \\
\hline People & $\begin{array}{l}\text { Use of forest products for } \\
\text { medicinal plants, construction } \\
\text { materials, firewood, and food }\end{array}$ & $\begin{array}{l}\text { Educate local people about } \\
\text { rules and policies governing } \\
\text { legal forest use }\end{array}$ & $\begin{array}{l}\text { Ensure that people continue to } \\
\text { value the forest and support its } \\
\text { conservation }\end{array}$ \\
\hline Nature & $\begin{array}{l}\text { Conserve forest use and } \\
\text { cultural values for future } \\
\text { generations }\end{array}$ & $\begin{array}{l}\text { Conserve forest use value for } \\
\text { renewable use by future } \\
\text { generations }\end{array}$ & $\begin{array}{l}\text { Conserve forest biodiversity } \\
\text { value for future generations }\end{array}$ \\
\hline Wealth & $\begin{array}{l}\text { Receive financial benefits from } \\
\text { the forest }\end{array}$ & $\begin{array}{l}\text { Exploit forest resources for the } \\
\text { economic gain of the local } \\
\text { people, e.g., timber sales, and } \\
\text { the agency, e.g., timber permits }\end{array}$ & $\begin{array}{l}\text { Ensure that local people have } \\
\text { the necessary resources so that } \\
\text { pressure on forests is reduced }\end{array}$ \\
\hline Power & $\begin{array}{l}\text { Forest agents enforce the laws } \\
\text { and keep illegal loggers out of } \\
\text { community forest areas Keep } \\
\text { migrants from using local forest } \\
\text { resources }\end{array}$ & $\begin{array}{l}\text { Ensure that communities are } \\
\text { adhering to the conditions set } \\
\text { forth in the GCF contract } \\
\text { Ensure more efficient use of } \\
\text { agency staff with respect to } \\
\text { forest patrols and monitoring }\end{array}$ & $\begin{array}{l}\text { Ensure that the state forest } \\
\text { agency prosecutes illegal forest } \\
\text { users }\end{array}$ \\
\hline
\end{tabular}

forest products. Reasons for this included lack of markets for nontimber forest products from the dry forest and lack of surveillance of illegal timber harvesters. The Menabe dry forest has extremely low productivity, which makes sustainable timber harvesting extremely difficult (Covi 1992, Randrianasolo 2000). Further, nontimber forest products are not profitable in the region, leaving no options for commercialization of forest products (Rakotomanana 2004). In addition, forest users reported that the state forest agency is unable to keep logging companies and migrant groups from extracting forest resources illegally. Forest users felt that they did not have the legal authority or the means to stop illegal cutting, even within areas managed by the community.

\section{State forest agency}

State forest agency personnel at the local level in Menabe and at the national level in Antananarivo indicated that the current GCF arrangement falls short of meeting the agency's goals. Both in the
Menabe region and beyond, forest agency personnel reported that the GCF contracts are not functioning as they should with respect to their interests in the People, Nature, Wealth, and Power categories.

Agency staff indicated that they would like GCF to serve as a mechanism for reducing, if not eliminating, illegal logging in community-managed forests. However, staff noted that a lack of understanding of the rules of GCF contributes to the continuation of illegal activities. Under GCF, communities are able to decide whether outsiders may have access to the forest, but they do not exercise this authority for fear of retribution. A mechanism is needed whereby communities can assert their authority or work in close collaboration with the forest agency to enforce rules. Agency staff identified a need for more education throughout the process of designing, signing, and implementing GCF contracts.

Agency staff also reported that GCF is not contributing to the economic gain of local communities or the agency. Communities are losing 
because timber continues to be extracted illegally. In addition, the GCF mechanism itself excludes the agency from benefiting from permit sales because this responsibility is transferred to the community under this decentralized management arrangement. Therefore, the Wealth-related interests of the agency are not being met under GCF contracts.

Finally, agency staff reported their interest in the conservation of forest resources for renewable use by future generations and in the efficient functioning of the state forest agency in general. The lack of transparency and accountability and a high rate of corruption are preventing the GCF mechanism from functioning as intended. Illegal timber harvest is reducing the amount of forest available for future generations, and unclear monitoring and evaluation methods, together with a lack of incentives to obey the rules, are contributing to delinquency on the part of community forest users and agency staff. Thus, the state forest agency is dissatisfied with the current GCF arrangement.

\section{Conservation-oriented NGOs}

NGO staff reported that the current GCF arrangement is meeting their People- and Naturerelated interests. The conservation and subsistence use zones within community forests are contributing to an environmental ethic among people by engaging them in the active management and monitoring of the resources they use. In addition, conservation zones are ensuring that the forest will be available for future generations.

NGO staff also indicated that, because productivity is so low in the dry forest, it is virtually impossible for communities to extract forest products sustainably. Although they would like communities to benefit financially, NGO staff noted that extractive benefits are an unlikely possibility, so they are working to develop nonextractive benefits such as tourism.

Finally, NGO staff both locally and nationally indicated that the current GCF arrangement is not resulting in the prosecution of illegal timber harvesters as originally intended. They cite corruption, lack of formal authority on the part of community members, and lack of motivation on the part of forest agency staff as reasons for the inability to curb continued illegal harvesting and penalize violators.

\section{DISCUSSION}

Results from this exploratory analysis of the multisector interests held by three participating actors in community-based, contractual forest management in the Menabe region of Madagascar indicate that the actors involved hold some similar and some differing interests. Specifically, the interests held by all three groups seem to converge around the Nature and Wealth categories and diverge around the People and Power categories. This finding confirms the importance of including the People category in the Power, Nature, Wealth, and People (PNWP) framework insofar as it encourages divergent yet extremely relevant interests to surface. These interests can then be addressed deliberately before intractable conflicts emerge. In addition, results indicate that the state agency is the least satisfied with the current management arrangement, and that interests related to Wealth and Power aspects of forest management are not accounted for under the current management mechanism. These results have implications for how the Gestion Contractualisée des Forêts (GCF) structure could be modified and for improvements that could be made under the current structure.

The interests identified by members of the three research groups, i.e., community forest users, forest agency staff, and NGO personnel, reflected the goals of each group. For instance, forest users, who rely on the forest for daily needs, identified interests that reflect their livelihood priorities. It should be noted that the current GCF structure meets the People- and Nature-related interests of community forest users, but not the Wealth- and Power-related interests. According to the PNWP framework, People and Nature represent fundamental building blocks of rural life in Madagascar. We submit three possible explanations for these preliminary results: (1) GCF is still evolving, and in time it will develop and improve its ability to respond to all four classes of interests; (2) the GCF model is not designed to respond to community interests in all four categories; or (3) the GCF contracts of Menabe are an anomaly with regard to their responsiveness to community-held interests. Additional research is needed to allow us to draw definitive conclusions regarding these three possibilities.

The state forest agency, which is the entity charged with managing forests, enforcing laws, and generating revenue for the state, identified interests that reflect its mandate. Worthy of note is the fact that the state forest agency is the least satisfied with 
the current GCF structure and/or function (Table 1). None of the interests identified by state agency staff are currently being met in a satisfactory manner. In some cases, this is because of the structure of GCF itself. For instance, one reason for decentralizing forest management is to reduce the agency's workload and empower local communities. The intended result is communities that have the authority to issue permits to individuals or groups who wish to extract timber from community forests, which would reduce the revenue to the forest agency from forest permits. In other cases, the forest agency is unsatisfied because of the implementation of the GCF contracts. Lack of good governance, i.e., corruption, lack of accountability, lack of transparency, lack of enforcement of rules, keeps the GCF mechanism from functioning as intended, resulting in negative impacts on the agency. The emergence of the state as a point of contestation and tension in community-based forest management is affirmed by other similar studies worldwide (e.g., Wily 1999, Schafer and Bell 2002, Kumar and Vashisht 2005).

NGO staff identified interests that reflect their commitment to biodiversity conservation. Interestingly, their People- and Nature-related interests are currently being fulfilled, whereas their Wealth- and Power-related interests are not. This mirrors the case for community interests. The reasons for this are difficult to identify without additional research, but we propose several possibilities:

1. As a conservation organization, the NGOs' first priority is biodiversity conservation. However, because the forests are populated, NGOs are obliged to work hand-in-hand with local people to ensure that conservation is achieved. Thus, NGOs may devote the bulk of their efforts to meeting its People- and Nature- related interests.

2. As conservation organizations, NGOs have neither the expertise nor the budget to invest in income-generating activities for local populations. Although NGOs would like local people to benefit from conservation, they are unable to ensure that this occurs.

3. Although the NGOs would like to ensure transparency and accountability in how the forest is managed, as a third party to the GCF arrangement they have no real standing from which to improve governance. Thus, NGO
Power-related interests are beyond their control. Again, these possibilities can only be confirmed with additional research.

Finally, our results suggest that the Wealth and Power interests held by all groups are the least accounted for under the GCF mechanism. Economic gain by the local community is limited by the peculiarities of the dry forest ecosystem. Although this is not a result of GCF per se, the fact that sustainable commercialization of forest products in this region is not currently occurring raises questions about the appropriateness of community forest management in ecosystems of this type. If one of the goals of GCF is economic benefit to the community, as suggested by the commercial use zone mandated by GCF, and if all parties involved are interested in seeing the community benefit economically from forest management, then perhaps the GCF arrangement in a zone of low forest productivity should be modified to account for these needs. One recommendation may be to explore nonextractive means for generating economic benefits from dry forests, such as tourism, direct payments for conservation, or carbon sequestration projects. We feel that the Wealth-related interests do not pose an absolute obstacle to community forest management in Menabe. Rather, the GCF mechanism needs to be adapted to the production potential of the local ecosystem. That is, GCF arrangements should be flexible enough to adapt to the productivity levels of different forest ecosystems and the respective needs and limitations of local communities.

That Power-related interests are not being met under the current GCF structure suggests an inconsistency between one of the main purposes of implementing GCF contracts and their outcome. As a mechanism for decentralizing rule making and management implementation, GCF is an attempt to change and improve governance. Nevertheless our results indicate that the governance-related interests held by the participating groups are not being met. Respondents are unsatisfied with the extent to which GCF achieves participation, accountability, transparency, etc. This finding suggests that, despite the rhetoric of good governance that justifies GCF, the practice of implementing these contracts may neglect key governance issues. This finding is corroborated by other studies that have demonstrated that efforts to decentralize development often pay little attention to how local governance arrangements reflect culturally charged struggles 
for power (e.g., Bebbington et al. 2004). To rectify this situation, additional analysis regarding the GCF mechanism and its implementation is needed. It may be that GCF is not an appropriate governance mechanism in all cases. It may also be that additional attention should be paid to key elements of good governance such as participation, clear rules, transparency, accountability, and monitoring and enforcement (UNDP 1997, IUCN 2004; J. Graham, B. Amos, and T. Plumptree, unpublished manuscript).

The results of this study indicate that groups differ with respect to certain interests when it comes to PNWP. Although this finding is not surprising, it is a useful reminder that forest management engages actors in many sectors who often have divergent stakes in the outcomes of management decisions and activities (Brechin et al. 2003). For the case of GCF in Menabe, these divergent interests compete with one another and result in tensions among groups of actors. For instance, there is tension between the forest agency and communities regarding the enforcement of rules, especially those concerning illegal and migrant loggers. Illegal logging occurs in a vacuum of rule enforcement and in areas in which market incentives are great. Because migrant loggers were not targeted in this study, speculation regarding their specific interests and motivations is difficult. However, we can say that illegal logging may threaten the integrity of GCF arrangements and the long-term viability of community management in Menabe. Additional research is needed to explore the overall dynamic and examine the ways in which decentralization is contested on conceptual and practical levels.

Our results also indicate that the PNWP framework complements existing knowledge about the decentralization of forest management. Previous studies have identified the conditions necessary for success. This study takes a step back and examines the design of decentralization arrangements. In a development context, we argue that forest management activities cannot focus solely on forests. Parties to community forest management hold multiple and often divergent interests that touch many sectors. The PNWP framework provides a lens through which decentralized governance arrangements may be designed to account for these multisector interests.

\section{CONCLUSION}

Decentralization of forest management is intended, in part, to respond more directly to local needs than has been the typical experience with centralized decision making. The logic behind decentralization of the forest sector is that local people who live close to the forest and rely on its resources are fit to manage it because they have context-specific knowledge and experience. In addition, decentralized government structures are intended to interact with forest users and are therefore more familiar with local particulars than centralized actors.

The results of this study indicate that, although decentralized forest management is a step toward meeting locally identified needs, it does not go far enough in responding to local interests, at least in the case of Gestion Contractualisée des Forêts (GCF). Forest management touches multiple sectors and therefore decisions or activities that focus solely on forest manipulation are not adequate for addressing local realities. For instance, forest management involves issues related to livelihoods, health, and education, i.e., People; forest manipulation, i.e., Nature; income generation and economic growth, i.e., Wealth; and governance and rule making, i.e., Power. In addition, forest users live their lives as whole people with interests and activities that are multisector or trans-sector (Selznick 1992).

The People, Nature, Wealth, and Power (PNWP) framework for assessing community-based forest management initiatives provides a structure for identifying the interests related to nonforest sectors that are involved in community-based forest management as well as those of different participating groups. This study suggests that PNWP could be a useful assessment tool. However, the challenge is to design community-based forest management structures and processes that at the outset are based on the PNWP framework. That is, deliberate attempts to design decentralized forest management with a PWNP approach may result in interventions that are more responsive to the gamut of interests and relationships held, take into account the different forest ecosystems and relative needs of communities, and therefore prove to be more sustainable in the longer term. 
Responses to this article can be read online at:

http://www.ecologyandsociety.org/vol12/iss1/art14/responses/

\section{Acknowledgments:}

Funding for this work was provided by the National Science Foundation Graduate Research Fellowship, an International Research Travel Grant from the Mario Einaudi Center for International Studies, and a Student Environmental Research Grant from the Cornell University Center for the Environment. We are grateful to the residents of the communities, forest agency staff, and NGO personnel who participated in this study.

\section{LITERATURE CITED}

Adams, W. M., and D. Hulme. 2001. If community conservation is the answer in Africa, what is the question? Oryx 35(3):193-200.

Agrawal, A., and J. Ribot. 1999. Accountability in decentralization: a framework with South Asian and West African cases. Journal of Developing Areas 33(4):473-502.

Bebbington, A., L. Dharmawan, E. Fahmi, and S. Guggenheim. 2004. Village politics, culture and community-driven development: insights from Indonesia. Progress in Development Studies 4 (3):187-205.

Bergh, S. 2004. Democratic decentralization and local participation: a review of recent research. Development in Practice 14(6):780-790.

Blaikie, P. 2006. Is small really beautiful? Community-based natural resource management in Malawi and Botswana. World Development 34 (11):1942-1957.

Borrini-Feyerabend, G., M. P. Pimbert, M. T. Farvar, A. Kothari, and Y. Renard. 2004. Sharing power: learning-by-doing on co-management of natural resources throughout the world. International Institute for Environment and Development, Tehran, Iran.

Brechin, S. R., P. R. Wilshusen, C. L. Fortwangler, and P. C. West, editors. 2003.
Contested nature: promoting international biodiversity with social justice in the twenty-first century. State University of New York Press, Albany, New York, USA.

Brown, D., and K. Schreckenberg. 2001. Community forestry: facing up to the challenge in Cameroon. Rural Development Forestry Network, London, UK.

Centre de Coopération Internationale en Recherche Agronomique pour le Développement (CIRAD), Deutsche Gesellschaft für Technische Zusammerarbeit (GTZ)-Polfor, MIRAY/Conservation International, SAHA, Tany Meva, and World Wildlife Fund, editors. 2002. Mise en oeuvre du processus de transfert de gestion des ressources forestières: rapport de l'atelier de capitalisation de Mahajanga. (Mahajanga, 2002). Eaux et Forêts, Antananarivo, Madagascar.

Chivian, E. 2001. Species loss and ecosystem disruption: the implications for human health. Canadian Medical Association Journal 164 (1):66-69.

Chivian, E., and A. S. Bernstein. 2004. Embedded in nature: human health and biodiversity. Environmental Health Perspectives 112(1):A12A13.

Covi, S. 1992. Inventaire forestier en forêt dense sèche dans la forêt du CFPF de Morondava Côte Ouest de Madagascar. Fiche technique no. 23. Centre de Formation Professionel Forestère, Morondava, Madagascar.

Denzin, N. K., and Y. S. Lincoln. 2000. Handbook of qualitative research. Second edition. Sage Publications, Thousand Oaks, California, USA.

Eaux et Forêts. 2002. Loi forestière et textes d'application. Eaux et Forêts, Antananarivo, Madagascar.

Edmonds, E. V. 2002. Government-initiated community resource management and local resource extraction from Nepal's forests. Journal of Development Economics 68(1):89-115.

Gauld, R. 2000. Maintaining centralized control in community-based forestry: policy construction in the Philippines. Development and Change 31:229-254. 
Glaser, B., and A Strauss. 1967. The discovery of grounded theory: strategies for qualitative research. Weiderfeld and Nicholson, London, UK.

Goodman, S. M., and J. P. Benstead, editors. 2003. The natural history of Madagascar. University of Chicago Press, Chicago, Illinois, USA.

Government of Burkina Faso. 2004. Poverty reduction strategy paper. Ministry of Economy and Development, Ouagadougou, Burkina Faso.

Government of Madagascar. 2004. Poverty reduction strategy paper. Ministry of Finance, Antananarivo, Madagascar.

Hempel, L. C. 1996. Environmental governance: the global challenge. Island Press, Washington, D. C., USA.

Hildyard, N., P. Hedge, P. Wovekamp, and S. Reddy. 2001. Pluralism, participation, and power: joint forest management in India. Pages 56-91 in B. Cooke and U. Kothari, editors. Participaton: the new tyranny? Zed Books, New York, New York, USA.

Kiss, A., editor. 1990. Living with wildlife: wildlife resource management with local participation in Africa. International Bank for Reconstruction and Development and World Bank, Washington, D.C., USA.

Klugman, J., editor. 2002. A sourcebook for poverty reduction strategies. World Bank, Washington, D.C., USA.

Kumar, C., and U. S. Vashisht. 2005. Redefining community-state partnership in natural resource management: a case from India. Development in Practice 15(1):28-39.

Larson, A. M., and J. C. Ribot. 2004. Democratic decentralisation through a natural resource lens: an introduction. European Journal of Development Research 16(1):1-25.

LeCompte, M. D., and J. Preissle. 1993. Ethnography and qualitative design in educational research. Second edition. Academic Press, New York, New York, USA.

Lourenco, W. R. 1996. Biogeography of
Madagascar. Editions ORSTOM, Paris, France.

McKee, J. 2004. Sparing nature: the conflict between human population growth and earth's biodiversity. Rutgers University Press, Rutgers, New Jersey, USA.

Menzies, N. K. 2004. Communities and their partners: governance and community-based forest management. Conservation and Society 2 (2):449-456.

Miles, M. B., and A. M. Huberman. 1994. Qualitative data analysis: an expanded sourcebook. Second edition. Sage Publications, Thousand Oaks, California, USA.

Montagne, P. 2004. Analyse rétrospective $d u$ transfert de gestion à Madagascar et aperçu comparatif des axes méthodologiques des tranfserts de gestion sous loi 96-025 et sous décret 2001-122. Consortium RESOLVE - PCP - IRD, Antananarivo, Madagascar.

Ostrom, E. 1990. Governing the commons: the evolution of institutions for collective action. Cambridge University Press, Cambridge, UK.

Oyono, P. R. 2004. One step forward, two steps back? Paradoxes of natural resources management decentralisation in Cameroon. Journal of Modern African Studies 42(1):91-111.

Pagdee, A, Y Kim, and P. J. Daugherty. 2006. What makes community forest management successful: a meta-study from community forests throughout the world. Society and Natural Resources 19:33-52.

Peluso, N. L. 1993. Traditions of forest control in Java: implications for social forestry and sustainability. Global Ecology and Biogeography Letters 3(4/6):138-157.

Platteau, J. P. 2004. Monitoring elite capture in community-driven development. Development and Change 35(2):223-246.

Rakotomanana, F. 2004. Etude technique et financière de la valorisation des produits forestières non-ligneux dans le corridor Menabe: Tubercules et Mokoty. Conservation International, Antananarivo, Madagascar. 
Randrianasolo, J. 2000. Capitalisation des experiences en gestions contractualisées de forêts à Madagascar: fichiers d'experiences. Intercooperation Suisse, Antananarivo, Madagascar.

Ravalomanana, M. 2006. Madagascar naturellement: Birth control is my environmental priority. WorldView Magazine 19(3):6-10.

RESOLVE Conseil. 2005. Evaluation et perspectives des transferts de gestion des ressources naturelles dans le cadre du programme environnemental. 3. Rapport final de synthèse. RESOLVE Conseil, Antananarivo, Madagascar.

Ribot, J. C. 2002. African decentralization: local actors, powers and accountability. Available online at: http://www.unrisd.org/unrisd/website/document. nsf/0/3345AC67E6875754C1256D12003E6C95? OpenDocument.

Schafer, J., and R. Bell. 2002. The state and community-based natural resource management: the case of the Moribane Forest Reserve, Mozambique. Journal of Southern African Studies 28(2):401-420.

Seidman, I. 1998. Interviewing as qualitative research: a guide for rearchers in education and the social sciences. Second edition. Teachers College Press, New York, New York, USA.

Selznick, P. 1992. In search of community. Pages 195-203 in P. Selznick, editor. The moral commonwealth. University of California Press, Berkeley, California, USA.

Smith, A. P., N. Horning, and D. Moore. 1997. Regional biodiversity planning and lemur conservation with GIS in western Madagascar. Conservation Biology 11(2):498-512.

Sorg, J. P., J. U. Ganzhorn, and P. M. Kappeler. 2003. Forestry and research in the Kirindy Forest/ Centre de Formation Professionnelle Forestière. Pages 1512-1519 in S. M. Goodman and J. P. Benstead, editors. The natural history of Madagascar. University of Chicago Press, Chicago, Illinois, USA.

UNDP. 1997. Governance for sustainable human development. UNDP, New York, New York, USA.

Uphoff, N. 1986. Local institutional development: an analytical sourcebook with cases. Kumarian Press West Hartford, Connecticut, USA.

USAID. 2002. Madagascar integrated strategic plan: FY 2003-2008. USAID, Antananarivo, Madagascar.

USAID, Center for International Forestry Research, Winrock International, World Resources Institute, and International Resources Group. 2002. Nature, wealth, and power: emerging best practice for revitalizing rural Africa. USAID, Washington, D.C., USA.

Vabi, M. B., C. N. Ngwasiri, P. T. Galega, and R. P. Oyono. 2000. The devolution of forest management responsibilities to local communities: context and implementation hurdles in Cameroon. Rural Development Forestry Network, London, UK.

Wiggins, S., K. Marfo, and V. Anchirinah. 2004. Protecting the forest or the people? Environmental policies and livelihoods in the forest margins of southern Ghana. World Development 32(11):1939-1955.

Wily, L. 1999. Moving forward in African community forestry: trading power, not use rights. Society \& Natural Resources 12:49-61.

World Conservation Union (IUCN). 2004. Governance of natural resources: the key to a just world that values and conserves nature? Briefing Note No. 7. IUCN, Gland, Switzerland. 